\title{
Forming the Concept of Crime in Theoretical System of Post Modernism
}

\author{
Tavasolizadeh Parviz ${ }^{1} \& V_{\text {Varvaii Akbar }}^{2}$ \\ ${ }^{1}$ Department of Law, Kermanshah Branch, Islamic Azad University, Kermanshah, Iran \\ ${ }^{2}$ Department of Law, Amin Police University, Iran \\ Correspondence: Tavasolizadeh Parviz, Department of Law, Kermanshah Branch, Islamic Azad University, \\ Kermanshah, Iran. E-mail: parviztavasouli@iauksh.ac.ir
}

Received: June 8, 2016 Accepted: July 9, 2016 Online Published: October 30, 2016

doi:10.5539/jpl.v9n9p102 URL: http://dx.doi.org/10.5539/jpl.v9n9p102

\begin{abstract}
One of the dimensions of social changing is the people's aspects in any era toward the topic of crime, punishment, and administration of justice as well as legal agenda. Therefore the concept of crime has passed historical changes base on the social contexts in which it is located. The connections and relations among the elements, that make the concept of crime, were variable and different. Some scholars concern the present era as a postmodern era which has been emerged after the era of modernity and it somehow has forced itself on societies. In this era all concepts and agendas have been changed in concept and discourse. The concept of crime and criminology has also been changed in both sides. The scholars of this area believe that metamorphosis happens in the concept of crime from modern era into a new critical and postmodern formation. Therefore this study is going to form the concept of crime in theoretical system of postmodernism. The findings of this study shows that crime in the era of postmodernism and in that conceptual system is a kind of "discourse constructed" and is a kind of function of the dominant power and social conditions .
\end{abstract}

Keywords: crime, criminology, criminal, postmodernism, discourse, power

\section{Introduction}

The expression of crime in criminology is as important as the word society for sociology. Criminology can be defined as the study of crime although the definition is not so careful; therefore to understand what the criminology means, the definition of crime is determinative. Furthermore, it is essential to define a crime in order to illustrate not only who is the criminal, but also what the content of criminology is. Different theoritian and scholars have discussed both the concept of crime and factors which affect on crimes, some believe that this concept is the result of biological elements and factors, some concern it as a result of psychological factors, and other scholars emphasize on social factors in forming the crime. Scrutinizing the historical evolutions of various theoretical aspects of crime definition from the beginning to the contemporary era revealed the wonderful insight. Experts of criminology believe that there have been three discourse changings or evolutions in crime. At first these have been the evolution from classical criminology of enlighten era of positive criminology then in critical criminology in postmodern. This study is searching the concept of crime in theoretical system of postmodernism regarding this historical classification, The main question defining how this concept is evaluating the rank of crime concept in theoretical system of postmodernism.

As a hypothesis, this research claims that the concept of crime is getting discourse metamorphosis, and in this critical discourse, the crime is a function of social structure, dominant power and mentality. This research tries to put this claim in discussion by descriptive and analytical method. The organizing of research content toverify the hypothesis is in the way that at first the definition of crime will be represented and then the aspects of this concept will be analyzed and discussed. After that the theoretical system of postmodernism will be scrutinized; finally the position of crime will be analyzed and discussed in different theoretical aspects from classical to postmodernism. Passing all these steps gradually and systematically the research tries to answer the main question presented in this study.

\section{Quiddity of Crime}

The concept of crime is one of the most complex concepts that most fields of humanities have tried to illustrate; 
if we focus on the Carl Menninger question, it is said that the worst crime is our ignorance of crime. As an exaggeration, it should be confessed that there is not obvious definition of crime and it is still hidden behind the pure legal analysis. Although recognizing the concept of crime depends on recognizing the concept and position of criminal law in humanities, it is worth to be discussed independently. This concept is the argumentative topic which is crucial to be discussed in Iran's criminal law, however the definition of crime is affected by the discussions in related majors of study.

\subsection{Definition of Crime in Islamic Jurisprudence}

There is no definition of crime in Imamieh Jurisprudence, and Islamic jurists define the crime base on the punishment defined in Islamic law, some contemporary Islamic lawyer and jurists believe that the crime is opposed to the (Devine) Quranic and Islamic traditional orders and preventions; it is committing an action resulting the individual or social corruptions; furthermore it is protected by devine sanctions (Gorji, 1993; p58)

\subsection{Legal Definition of Crime}

Crime is any act or omission of act which is punished by law (article 2, Islamic criminal law, approved in July, $\left.29^{\text {th }}, 1991\right)$.

In addition to define the concept of crime in various courses, the definition in criminal law should be mentioned.

\subsection{Crime in School of Absolute Justice}

Crime is the violation of moral task, in other words, crime disturbs moral discipline, and the punishment is pain or hardship to relief this disturbing. (Baher; and Davar, 2000)

\subsection{Crime in Classical School}

The school of classic, which is mentioned as utilitarianism by some of lawyers and jurists, defines the crime as a phenomenon which harms the social benefit. In fact crime is a breach of social contract rooted in public benefits. (Ardebili, 20018 p; 82).

(1) Islamic canonist or consultant. (2) Sharia. (3) Divine guarantee. (4) pure justice

Gradually lawyers and jurists believe that any violation in any nation's law resulting from external factor can be called crime providing that it is not because of doing legal task or order, and it is worthy to be punished. (TajAlzaman, 1985; p43)

Consequently, the written laws of countries play the central role in defining and recognizing the criminal behaviors, so; legally whatever causes the criminal behavior is defined as a crime in the rules and written laws of countries. Everywhere there is a crime, there is a rule since the simplest definition of crime is any kind of manner or behavior violating the rule. (Gidenz, 1995; p 457).

After the basic survey of crime concept in various aspects, this study tries to scrutinize this concept in theoretical system of postmodernism. Before studying this part it is essential to introduce the approach of postmodernism and its main subjects.

\section{Reflecting on Theoretical System of Postmodernism}

This study is based on scrutinizing the concept of crime in critical thinking while presenting the theoretical principles of postmodernism.

Should the postmodernism be concerned as a part of modern world?

Is postmodernism resulting from radical continuity or break?

Is postmodernism a principle changing, is it a position resulting of one way thinking or one way behavior? (Sarap; 2013; p: 177).

There is a time of appearing different intellectual currents in various human science specifically human science during the 1960s and 70s. For example the emergence of post structuralism in early 1970s in Frence is intellectually concerned as expansion of critical currents against structuralism. School of post structuralism ignored all claims of structuralism such as, identity, certainty, comprehensiveness and finally denied all these concepts in structuralism.

This denying finally opened the new ways to research and study in human science. In other words, instead of the concepts of unity, universallity and public acceptance in structuralism, it emphasized on intensity, pluralism, individualism and distribution of concepts. It also refused any pluralism, dualities and contrasts which are fixed and certain in structuralism. Postsructuralism opened a way of emergence for new powerful and challenging current called postmodernism, that its principles were mainly the principles of post structuralism. Therefore 
postmodernism emerged in the last three decades of $20^{\text {th }}$ century. The approach of postmodernism is a kind of reaction against modernism or in other word is a kind of deviation or interruption or getting distance from modernism.

The main core of postmodernism is not only general distrusting toward all theories and holistic applications but also refusing any ideologies, teaching, doctrines and finally rejecting all Macro-Narratives in all scientific fields, and fields of human knowledge and wisdom. (Nozari, 2006, p; 187 to 183).

Post modernism is a kind of big deny rather than belonging to special era, denying the modernity. This deny keeps the various cults of post modernism together. However, it is known by its attracting to modernism and it criticizes the modernity not to do all its goals and promises, and consequently put the modern society into crisis. Modernity could not establish the better and wealthier world for humanity (MoiniAlamdari; 2006: 128).

\subsection{Kent Tampson Presents the Following Features for Post Modernism}

1. Post modernism is a reaction against the heritage of enlightens and the phenomena such as power, technology, science, wisdom and progress.

2. Post modernism is against unity and convergence, and it believes in promoting the reality and pluralism.

3. This thought is going to reject not only the enlightening imperialism because of special political approach but also political priorities defined based on the liberalistic and Marxists thought.

4. It concentrates on pluralism, local governing and furthermore it centralizes the issues and problems of minorities, women, religious groups, homosexuals and others who are not concerned as important members of society .( 2008: p: 90 to 96$)$.

5. The idea of post modernism talks about the end of epistemology. This approach causes that the method of relativistic dominates the positions of cognitivist. While in modern thought the reason and experience were the circumstances of understanding, in post modernistic idea both factors were considered as a limitation of understanding. We recognized the elements or phenomena with our language and cognition, in other words our understanding of reality is limited to the discourses in which we think. Meanings are not inherent but discourse based, there is a veil of language and discourse between human and external world. (Bashirieh, 2007:422)

Postmodernists reject the theory of supra discourse or supra narrative and believe that it is not only impossible for social science to justify the supra discourse theory but also it is not desirable since trying to expand and impose one discourse means to ignore the other cultures and civilizations; consequently it is imposing some king of violence. Postmodernism believed that the modern scholars of social science are not independent but even corrupted with the powers. Postmodernists believed that all knowledge contains the power links and connections. As Foucault said :evrywhere the power is applied, the knowledge is produced (Nasri, 2006, p10-11). In postmodernism thinking, the image of Dekart and Kuntz possess the subject, and as Lackan said "the symbols dominate the human life in holistic networks and before the birth of human symbols, which creates human with flesh and blood, mixed together and give birth to the human. (Gier, 2001; p 107).

From the anthropology point of view, postmodernism refused the existence of human and it is belived that humad is made. Human emerged variously in the shadow of various discourse. In postmodern paradigm, while there is a topic of anthropology to discuss, different symbols come up; such as, postmodern anthropology, reflective anthropology, post structural anthropology and cybernetic anthropology which all have the same issue on a kind of treatment toward post-human, they have distinctive features though. Something is presented called human end and collapse of integrated identities. The human as a center of modern world is demolished by works of Foucault, Lackan, Deluz and Leotar There is no central human base on these scholars. Michal Foucaultannounced the idea of human endless, following the Nietzsche, in his book named "the order of things".

As Nietzsche announced the death of God, the Foucault's idea is based on inventing human. He believes that what emerged in different institutes such as prisons, schools and Asylum were bodies which were useful, productive and submissive.

Foucault claimed that the collapse of human returns to the views of Nietzsche, Marx and Freud as the tradition of subject's mind originality is doubted.

The scholars and intellectuals such as Lackan and Foucault thought that the stable self-identity was always an illusion, and human is the product of discourse and language. Today instead of probing a friendly modernism in order to get a deep and original self-identity; we are sometimes celebrating divergence and our decomposed inclinations. (Ghezelslfi, 2007: 146-148).

After defining the concept of crime and analyzing its definitions as well as scrutinizing the theoretical system of 
postmodernism, this research focuses on analysis of the main topic- forming the concept of crime in the theoretical system of postmodernism. Before going to the main topic the research tries to analyze the crime and its position in both classical and positive approach using the historical approach, and then getting back to the main topic.

\section{Analyzing the Position of Crime in Various Theoretical Approaches from Classical to Post Modern Era}

\subsection{Classical Criminology}

The scientific views toward crime began in $18^{\text {th }}$ century. [After that] the principles of classical approach were made. Rationalism did not care about the reasons of crime and generally focused on establishing the discipline. There was not an idea of punishment at the center of classical approach; rather it was preventer and well-proportioned. The classical model focused on rationality, freedom and human will, and it was a kind of reaction against criminal systems and the system existed in 1789. The school of classic was not interested in studying criminals but the studying of rule making and the legal process was the center of its attention. (Carrabine, 2004, p: 33).

This model presented a rational version of human being; that base on this version human behaves spontaneously. This kind of criminology did not pay attention on analyzing the human factors, but it focused on finding way to monitor and guide this behavior by effective rational persuasion, among scholars of this school of thought. There are two outstanding features such as Cesare Beccaria and Jeremy Bentham (NajafeeTvana, 2014, p 90-99)

\subsection{Positive Criminology}

Classical criminology was challenged by positive approach in $19^{\text {th }}$ century in this school of thought there are some scholars such as CeasarLamberoz, Enrico Ferri, and FrancissGaltan who all chose more scientific and practical approaches toward criminology, [furthermore] they used anthropological and psychological techniques and even some other techniques of human science to do so.

The positivists believed that the criminal behaviors were determinable rather optional, therefore it focused on treating the criminals not punishing them. The modern and positive approach toward the crime is a nature-believed approach which defines a science as an objective process which its goal is predicting and monitoring the world. (Valad and others, 2001: p; 367).The positivist approach has an appointed and dogmatic point of view toward the concept of crime. Despite of the classical approach, positivists believe that individuals are directed to the crime and wrongdoings by the external forces which are not in their controls, and these factors or forces can be identified and measured by scientific attitude. The positivist's point of view has a biological, psychological and sociological approach which defines criminal and perverted behavior by using scientific logic. (Brown, 2005, p: 28). The biological positivists were presented at first by Lombro2. He tried to categorize different groups of people based on their biological and radical differences. Therefore this school of thought believed that individuals were born criminal, and they are not turning to be criminals through their life. (White, 2001, pp. 76-79)

The psychological theories of positivism have a different historical root and show the various directions about the crime and criminal activities. In this approach the crime is happening either as result of biological problems caused by external factors (such as war wounds) or as a result of internal psychological factors (mental illness), both these factors were treatable, therefore these factors change individuals into criminals it means that they were not born criminals. This attitude assumes a criminal as a patient and tries to treat this illness and patient. (The same; 81). Generally in modern and positive theories there are four interrelated elements including: the government and judiciary systems, victims, criminals and general people. Studying the development of links of these elements is the duty of positivists and modern theories which have been formed through passing the time. (Lea 2002, p, 200).

\subsection{Critical Criminology}

The modern and positivistic theories of criminology have been criticized because of their one way approach which is close to natural science since 1950s, and these critics touched their climax when the critical criminology emerged. The new and critical theories emphasized on three elements, such as power, discourse and mind. The approaches such as post modernism, labeling and Marxism are the most approaches to explained the crime including three features inherently. Although the post modernism criminology is also critical, it stands beyond all critical criminologists. Since other approaches do not criticize modernistic process and criminology that much; the post modern criminology rejects all modernity and its observational views toward the world. In critical approaches crime is not a simple law violation or law breaching, but it is a subject which is made by the process of interactions of social reactions and power (Munica, 2004; p145). 


\subsection{The Labeling Theory and the Crime}

This theory has root in symbolic interactions. The main focus of this theory is on the power of labeling and forming the deviational nature affected by this power. The eminent theoreticians of this theory are Harward Becker and Sour, in this theory the crime is what others label. therefore there is no behavior to be concerned as crime by itself. The main character of this study is its focus on the power of labeling on people who are more deprived and marginal and less powerful in a society; and there is no crime and criminal until there is no such a power, therefore deviational behavior is a subjective coined resulted from labeling power to others.

The labeling approach is the starting step of new post modernistic approach. (Sotoudeh, 2001; p.66).

\subsection{The Marxist Theory of Crime}

This approach mainly rooted in Carl Marx theory and believes; and it believes that the crime certainly happens in capitalism and it criticizes the positivism in order to study the minor factors to explain the crime; that is why it is unable to concern more major factors defining the crime. In capitalistic system it is more probable to define the poor behavior as a crime by rich level of society, in this approach, inequality of wealth and power is considered as a reason of alienation and immorality. In Marxist's point of view, the crime is a behavior which is committed against the basic rights of human, such as the benefit's equality of capital among humans, and caused the social damages or injuries. (White and Haunes, 2000, p98).

Marx believes that crime is a phenomenon which is specific to Capitalism and by changing capitalism, it is vanished. Also Marx applies the concept of self-alienation for the concept of Anomy in Dour Kim's works, this concept is reflecting of society to the crime and criminals. In fact this is a social reaction that causes the feeling of individual self-alienation and it gradually keeps individuals away from the society. (Ahmadi, 2002:p61).

Marx and most of his followers believed in conflict, the crime has a close relationship with constructive and complex social field which plays a crucial role in its emergence. Special features of capitalism such as private ownership, social and economic classification, and unequal distribution of facilities and dominance of economic and political power on low and judiciary system turn the crime to be part of capitalism. (The same, pp. 60-61).

However, the author of this research has introduced and defined the crime and conceptual forming of crime in various criminological theories such as classic, positivism, critical and etc. findings show that the concept of crime gets different dimensions in different theoretical systems. As every theory has its own special definition of crime, it discussed the critical theories of crime are among those of latest ones. They emphasized on three elements including mind, power and discourse. Although the postmodern criminology is a kind of critical, it stands beyond all other critical criminology, other approaches do not criticize the process of modernity and modern criminology but the postmodern criminology rejects all modernity and its observational point of view. Therefore following this topic the concept of crime in theoretical system of postmodernism is scrutinized as a main topic of this research.

\section{Forming the Concept of Crime in Theoretical System of Postmodernism}

As mentioning in introduction, the major topic of this study is concerning the position of crime concept in theoretical system of postmodernism. A main hypothesis of this study claims that the concept of crime gets the discourse metamorphosis in the theoretical system of postmodernism and in this critical discourse, crime is a function of social structure, and dominant mind and power, in this part the author is trying to analyze this topic and scrutinize the rights and wrong of this topic. New theories on deviations and criminology has less been focused in Iranian academic community, and researchers have not probed the crime and malevolent behaviors in the approaches of postmodernism; regarding this shortcoming, this study tries to cover the emptiness of working and studying in this field. As it presented earlier, postmodernism represents a vague pluralistic and temporal approach of social world and break the structure of major supra narrations for which modernism search. In this point of view all process of modern criminology is deceiving. In this frame work, all earlier theories of modern era which are going to recognize the fundamental causes of crime by a critical approach are not acceptable; and from postmodernism points of view the crime and criminology were always local, partial and haphazard and [even] impressed by the power; and they cannot reveal the trueness of pure crime; however the theory of postmodernism in criminology was presented in the middle of boring caused in modernism, and enlighten at the early 1990s; being discursive, and subjective and emphasizing on the elements of power are the three characters of postmodernism approach toward the concept of crime and malevolent in behavior. The modern positivism claimed that criminology is the rational and scientific endeavor toward the process of crime, and following this method it mainly presented the massive and rational theories about interpersonal relationships, cultural heritage and social structures. But the post modernism challenges this kind of view, and it concerns the modern project of 
the scientific and objective tools delusive and surpluses in order to help the society. Both analyzing the crime, public theories of crime and searching for ensembles in postmodernism point of view which are supra narratives which have been harshly condemned. Although modernism tries to overcome the relativism both in theory and practice and concentrate on commonality, in the other side postmodernism considers the relativism as the permanent characteristic of world. (Muncie, 2004, p 146), one of the elements which is at the center of attention of postmodernism, in a process of crime is language. The modern thought believes that language in neutral and partly is an instrument for individuals to get their goals. But in the postmodern point of views discourses are the methodical language systems and language always is repeated by phones, and the media never is neutral. Language always gives credit to join approaches and belittle and underestimate some others and it is the starting point of forming crime and maltreatments in society. (Vold and others, 2001, p163). In fact the post-modernist criminology focuses on language products in contrasting with Marxists who concentrates social and economic suppressions. It believes that criminal rules and laws (themselves) are kinds of language which create the dominant relations, and the dominant criminal discourse is exclusive, and it defines the limiting rules.

Generally postmodernists try to analyze the crime and criminal as they are resulted from power or as they are produced by the power. The power which tries to control and limit the people's behaviors is not powerful. Accordingly to this approach the crime is not only what it is defined by criminal law, but it also is the power or ability which imposes some people's desires, and demands on the others. In any social context crime is the power of denying others. (Niazeo and others, 2014: p 85).

Michel Foucault is one of the experts who criticizes the modern criminology with the postmodernist approach. Considering discourse analysis he finds the element of the power behind any explained theory.

Foucault believes that the duty of criminology is not resolving the problem of crime; furthermore it is for developing and organizing the power and observation. He considers the criminology as a discourse which extends and expands the connections of power and observations. (Carrabine, 2004: pp.89-90). Foucault mentions the extended disciplinary discourse that he thinks the prisoners corrections, lunatic detention and observing the industrial workers such as training and educating children all are part of prison called society, which is emerging. In this [kind of] society not only the crime and behavioral corruptions are controlled but the kind of chaos and breaking the norms also is controlled. Foucault considers the changing of punishment in classical societies which stands upon physical torturing and body punishments and compares them with sub-politics of modern capitalism which stands on observation and normalization.

Torturing remains in fame work of modern criminal justice, although the criminal punishments, the harshest form of itself, do not focus on body, it concentrates on spirits. The punishment should affect on mind, spirit and rather affects on body. Foucault believes that power is published anywhere. And it acts by resulted discourse. Therefore criminology is a discourse which represents the sets of ideas and its special language about crime as the subjects which is under study. In fact Foucault approaches the link between knowledge and power for more controlling and sub serving human body and spirit in modern society. (Foucault, 1997, p 27).

Also" Hennry and Milovonovich"in the book named blushing criminology toward postmodernism" claim that they introduced kind of postmodernism criminology. Establishing criminology is a kind of theoretical postmodern approach includes various critical theories. The principle of this subject is that the crime and control content be separated from cultural and structural principles in which it is formed. Establishing criminology rejected the modern topic of traditional based on which crime and criminology can be analyzed and rectified from the processes of social production and separately from principles. Instead of defining factors caused the crime, the establishing criminology is searching the links which reproduce the crime. This theories avoid from analyzing the crime factors and focuses on genealogy, seducement, discourse, and social constructivism, as well as Structuring as a method of thinking on crime, the principle of crime concept is unequal relationship of power which is constructed in social form of informed in discursive framework. These two intellectuals mainly emphasized on the element of power. Because they believe that crime is the power of rejecting the others' ability to make difference. (Carrabin, 2004: p.95). As it considered earlier, the concept of crime and criminology gets the different meaning based on the theoretical approach in which it is analyzed and studied; therefore crime has got the various discursive meaning from the claimed approach to new critical one. This study as its main concern was going to probe the concept of crime in theoretical approach of postmodernism and findings illustrates that this concept gets the new dimensions in postmodernism and gets the critical characteristic, in a way that crime changed into discursive concept which it is an output of mind and structures of power as well as social constructs result. Analyzing and researching the issues related to problems in society, there are various approaches for which can be applied in a way that each topic can be studied in various attitudes and fields such as legal, political, economical and social, as well as cultural. Following this attitude, this study is going to analyze the topic of 
crime and criminology in legal dimensions.

\section{Discussion}

This study tries to find out the position of crime in a theoretical system of postmodernism and find out how it is analyzed in this system. The hypothesis is that the concept of crime is changed in discourse or has metamorphosis in discourse, and in this critical discourse the crime is a function of social structure, mind and dominant power to scrutinize this hypothesis. This study categorizes the topic into four parts. First it scientifically analyzes the concept of crime and scrutinizes this concept in different point of views and various dimensions. Then it discussed the approach of postmodernism and analyzed the thinking principles of this approach. Next the researcher tries to analyze the position of crime in different theoretical system from classic era to postmodernism. The studies show that crime gets different dimensions in different theoretical systems, while we are observing the discursive changing in crime from classic era to postmodernism. To do this, the differences and similarities of each of these theories and discourses have been scientifically probed. the classical paradigm did not attend on criminal but focused on disciplinary management. Positivism considered the criminals as an object in criminology and tried to study this object practically and in positive approach. In fact one character of the positivism is using the logic of positivistic science. Although the positivism has continued so far and has a vast dominance in criminology, recently it has been discarded by forming critical approach and emerging new theories. In critical approach, the object does not analyze the crime, regardless of its values and benefits that is contrary with positivism. Base on its benefits and orientation, it introduces some individuals and groups as a criminal. Critical paradigm tries to reveal the identity of groups who construct the crime, it is a duty to support the minorities and even worker in contemporary societies. This approach focuses on the abnormality of crime element and considerate its subjectivity and constructive. Among all critical approaches toward crime, the postmodernism as a distinctive paradigm challenges the theoretical structures of previous approaches, although postmodern criminology is a kind of critical, it stands beyond all critical criminology, since other approaches do not criticize the process of modernity and criminology, furthermore the postmodern criminology rejects all modernity. In postmodernism discourse, the crime is constructed by influential and powerful individuals. In fact the modern criminology concentrates on language product contrasting with Marxists who focus on economical and social suppressant. It also believes that the criminal rules are a kind of language which creates the rules of sovereignty. The dominant criminal discourse is banishing and exclusive as it defines special rules to banish.

The resolution for this challenge is to abolish the defining power of influential and powerful people. Therefore the findings of this study are proving the main hypothesis of this study which claimed that the crime is produced as a discursive topic and the criminal in the theoretical system of postmodernism. In this discursive atmosphere, it is formed and produced as a criminal.

\section{References}

Abosiashelghi, M. (2009). Modernity and postmodernity in translational relations. Monthly magazine, year: 24, NO 2 and 3.

Ahmadi, H. (2004). Sociology of deviance. Tehran: Samt.

Ardebili, M. A. (2001). General criminal laws. Tehran: Mizan.

Bashirich, H. (2007). Logic in politics. Tehran: Negah. Hoaser.

Carrabine, E. (2004). Criminology: a sociology introduction. London:Routledg.

Dehkhoda, A. (1998). Dictionary (loghtnameh). Tehran: Tehranian.

Fattah, E. (1997). Criminology:past,present and future, a critical over view. macmillan press.

Foucault, M. (1991). punishment and surveillance: birth of prison (translated: Sarkhosh, N., \& Jahandideh, A.) Tehran: Nai publication center.

Ghezelsfeli, M. (2007). the characteristics of Epistemology of idea in pre- modern, modern and postmodern. political Science research paper, 3(1).

Giddens, A. (1995). the sociology (translated: Sabouri, M.). Tehran, Nai.

Gier, A. E. (2001). the postmodernism and the critic of bio-environment (translated: Sabeti, E). Tehran: Cheshmeh.

Gorji, A. (1993). legal essay. Tehran, university of Tehran.

Lea, J. (2002). crime and modernity. sage publication. 
Moinialamdaree, J. (2006). methodology of new theories in politics. Tehran, university of Tehran.

Muncie, J. (2004). youth and crime. sage publication.

Nahafitavana, A. (2014). Criminology. Tehran, AmozeshvaSanjesh.

Nasri, Gh. (2006). postmodernism and the functional study: the essentials of methodology. the quarter magazine of functional study, 9(1).

Niazi, M. et al. (2014). turning discourse in defining crime; from classical era to postmodernism. the magazine of detective, 2(29).

Nozari, H. (2006). forming modernism and postmodernism. Tehran. Naghshejahan.

Saliba, J. (1987). Dictionary of philosophy (Translation: Sanei. M). Tehran: Hekmat publication.

Sarap, M. (2003). The basic guidance on post structuralism and post modernism (Translated by: Tajik, M). Tehran: Nai publication house.

Sotoudeh, H. (2007). Social pathology. Tehran: Avaye-e-noor.

Tajzaman, D. (1985). Who is the criminal and what is the criminology? Tehran: Kayhan.

Vold, G. et al. (2001). theoretical criminology (translated: Shojaee, A). Tehran, Samt.

White, R. (2001). an introduction to the crime and criminology (translated: Sedigh, M). Tehran, Dadgostar.

White, R., \& Haines, F. (2000). Crime and criminology. Oxford University press.

\section{Copyrights}

Copyright for this article is retained by the author(s), with first publication rights granted to the journal.

This is an open-access article distributed under the terms and conditions of the Creative Commons Attribution license (http://creativecommons.org/licenses/by/4.0/). 